\title{
Historical Development and Special Building Structures of In-earth Embedded Houses
}

\author{
D. Bozsaky \\ Széchenyi István University \\ Department of Architecture and Building Construction \\ Egyetem tér 1, 9026, Győr \\ E-mail: bozsaky@sze.hu
}

\begin{abstract}
Earth houses have been traditional residential buildings for a long time and their three different types (in-hill house, cave dwelling and atrium house) were separated during the early history. Modern earth houses appeared in the 1960s in the USA but spread only after the first oil crisis. Earthsheltered houses became popular nowadays because of their several benefits (environmentally friendly, economical, energy savings, landscape protection). Unfortunately they have some disadvantages (negative prejudices, high building costs, special building constructions, complicated design and construction). Several design aspects (orientation, ventilation) are extremely important for in-earth embedded houses. Because of the nonconventional loads and landscape situations they have special building and supporting structures. They had also extraordinary damp-proofing and thermal insulation problems, this is why special solutions are needed to have pleasant and comfortable indoor atmosphere.
\end{abstract}

Keywords: in-earth embedding, earth-sheltering, special building structures

\section{Introduction}

In-earth embedded houses are not recent forms of the residential buildings. This tradition can be traced back thousands of years. The earth architecture today has been developed so far that it is now regarded as an architectural guideline, which can become a key element of the sustainable development of built environment. This approach may be able to solve the aesthetic and environmentally harmonization with the landscape; the smart energy consumption and the healthy living environment can be taken into consideration in the same time.

This paper shows the historical archetypes of the kinds of in-earth embedded houses from ancient times to modern earth architecture. It summarizes the most important specific design aspects, advantages and disadvantages of these extraordinary buildings. It introduces the special supporting structures and the main damp-proofing and thermal insulating problems of them. 


\section{The Historical Archetypes of In-earth Embedded Houses}

Residential buildings that were embedded into earth always served as human shelters. In the beginning, people used naturally shaped natural formations (caves) used as protection against elements and wild animals. Later people were able to create habitation for themselves with their own creative activities. Since then, people built residency with their own hands that we call construction activity.

At first, natural materials for construction were used. Then earth became important building material such as wood and stone. From hillsides, where the hardness of rock allowed artificial caves were able to slot with the use of simple mining tools [6]. Where soil conditions allowed in-ground pitted houses could be made (Fig. 1). Their walls were entirely or partially formed by the side walls of the pit dug into the ground [11][12]. The roofs of pit houses were probably made of stone or wood that were covered with earth.

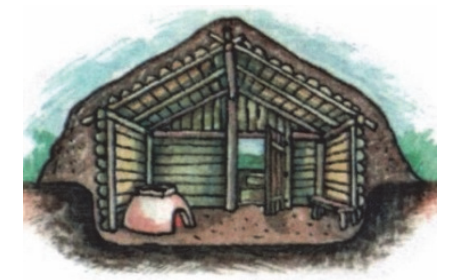

Figure 1: Draft of a half-pitted house [6]

This ancient type of residential house was applied for a long time, because the construction was easy and cheap; in winter it was easy to be heated; it ensured pleasantly cool indoor climate in the summer and protected against wild animals, and, in addition, it was hard to burn down during a potential robbery attacks [4].

\section{The Types of In-earth Embedded Houses}

Three types of in-earth embedded houses were developed throughout ages that are called cave house, in-hill house and atrium house (Fig. 2).
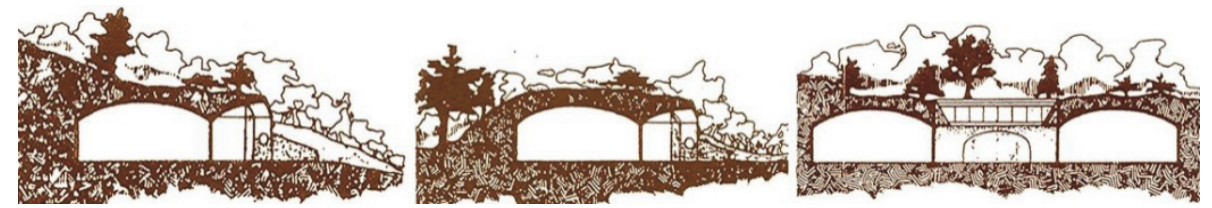

Figure 2: Types of in-earth embedded houses: cave house, in-hill house and atrium house [4]

\subsection{The Cave House}

The basic concept of man-made cave house comes from the image of natural cave. The cave dwellings can be built easily in hilly, sloping terrain. Typically it has one front facade. The other facades, side walls and roof are covered with earth. It warrants the 
freest architectural forming, because cutting into the hillside any form of architectural plan is available and it is suitable for multi-level layout.

In mining areas every citizens lived in such houses. Best known example is the city of Matera (Fig. 3) in Southern Italy. The "sassi" dwellings - that were declared as a part of the World Heritage in 1993 by UNESCO - were inhabited until 1950s [19]. In some cities of (e.g. Troo) the Loire Valley (France) and in Granada (Southern Spain) part of the population still live in cave houses hollowed into the rock.

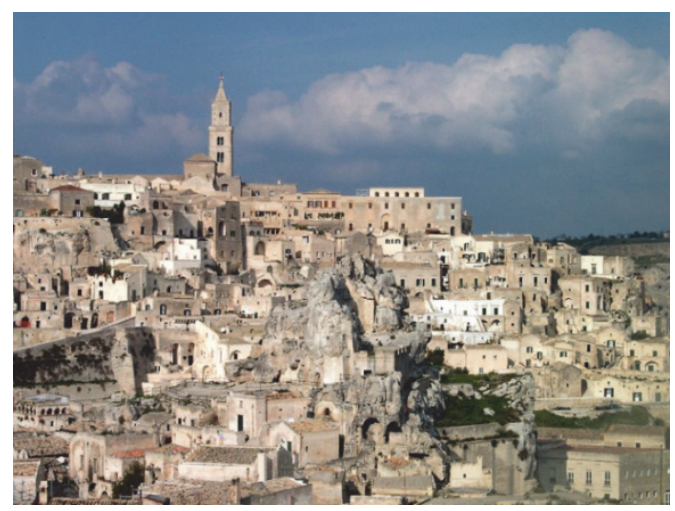

Figure 3: Cave dwellings called "Sassi" in Matera (Southern Italy) [19]

The underground cities in the area of Cappadocia (Turkey) are also well-known worldwide. In the relatively tractable volcanic tuff cut cave dwellings were shelters of the early Christians. The most famous in-rock villages in this area are Kaymakli, Derinkuyu.and the fortress of Uchisar. Similar homes we can find near Kandovan (Iran), Gondrani (Pakistan), in several provinces of India (Aurangabad, Rajagriha) and in the Caucasus (Georgia, Armenia).

Along the Yangtze River (China) we can meet numerous cave dwellings cut into the loess wall. In Chinese called "Yaodong" homes have been used for centuries, especially by the poorer classes (Fig. 4). Nearly 20 million Chinese still live in cave houses such along the river [14].

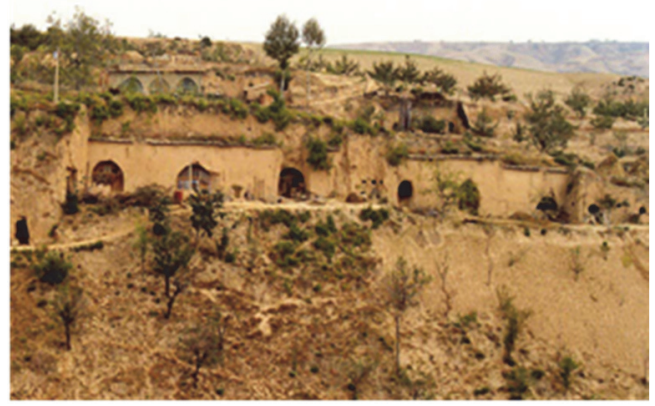


Fig. 4: „Yaodong” cave dwellings cut into loess wall (Yangtze river, China) [14]Lots of rock-cut cave dwellings are located in the rocky and arid regions of North America. The best known region among these is in the Mesa Verde National Park (Colorado) in Santa Clara Canyon (New Mexico) in the United States. The finest examples of cave dwellings are the nearly 1000 year-old Quarenta Casas in Mexico, Chihuahua province that were built by the Tarahumara Indians.

At present, many people live in cave dwellings in North African countries. A wellknown example is located near the city of Bandiagara (Mali), where the members of Tellem tribe built a complete settlement of rock-cut cave dwellings.

Many cave houses erected since the $13^{\text {th }}$ century are located in Hungarian mountain areas (such as Gerecse Region, Northern Mountains, Upper Balaton Lake Region, Sokoró Hills, Tolna Hills). Two main types of these dwellings are: natural caves used for housing (hermit caves) and artificially formed cave dwellings cut into limestone, loess, or volcanic tuff.

Best known hermit caves (Fig. 5) are the Saint Ivan Cave, the Báthory Cave (Buda Mountains), the hermitages at St. Michael's mountain (Börzsöny Mountains), the hermitages at Mátraverebély-Szentkút (Fig. 6), and the monk apartments in Tihany (Lake Balaton) [9].

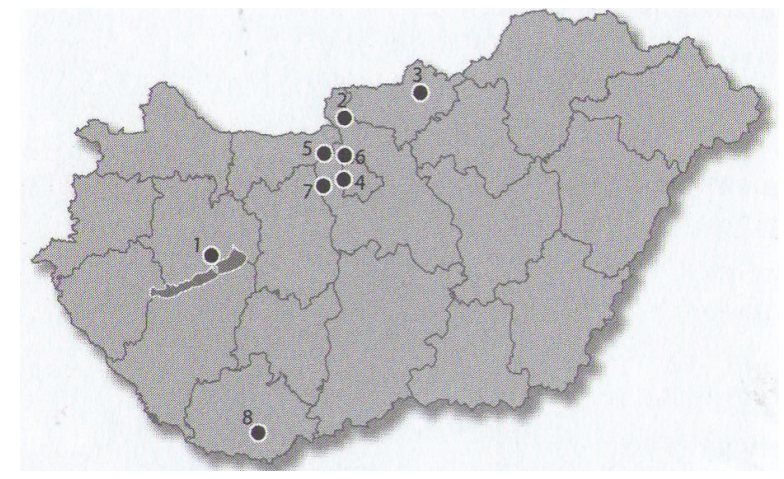

Figure 5: Hermitages in Hungary. 1: Tihany; 2: Saint Michael's mountain; 3:

Mártaverebély-Szentkút; 4: Saint Ivan Cave, 5: Máriaremete; 6: Báthory Cave; 7: Budaörs; 8: Jakab Hill [9] 


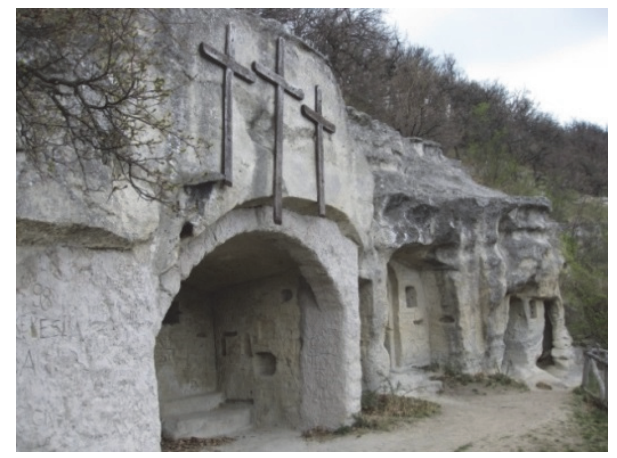

Figure 6: Hermitage in Mátraverebély-Szentkút (self-made photo)

Man-made cave dwellings (Fig. 7) were applied at territories where population dealt with the earth (mining, quarrying and viniculture). Several cave dwellings are located in Nógrád and Borsod-Abaúj-Zemplén County cut into volcanic tuff. These residents were mainly created for the poors in Cserépváralja and Cserépfalu. 10-15 of the cave dwellings in Szomolya (near Mezőkövesd) are still in use [9].

In Heves County (particularly at Eger area) several cave dwellings are cut into volcanic tuff. From the $19^{\text {th }}$ century the majority of the population in the village Noszvaj lived in cave dwellings and even in the 1970s 40 existing in-earth apartments were registered. In Egerszalók in the 1980s were many one-room cave dwellings that were built in the turn of the $19^{\text {th }}$ and $20^{\text {th }}$ century. Many of them are now under protection [9].

The cave dwellings and wine cellars were cut into rhyolitic tuff in Andornaktálya. Numerous wine cellars were used as dwelling-house in the first half of the $20^{\text {th }}$ century in Sirok and Ostoros [9].

Several notifications from the $18^{\text {th }}$ century mention the (mainly limestone) rock-cut cave houses in Buda Mountains. 24\% of the population of Budafok (2700 people) lived in such houses [2]. In the 1950s in Budafok and Budatétény 374 cave houses were registered; many of them were used as residential buildings until the 1970s [2].

In the area of Transdanubia we can find man-made cave dwellings cut into loess walls in Upper Balaton Lake Region (e.g. Balatonkenese, Balatonendréd, Ádánd), Sokoró Hills (e.g. Pannonhalma, Nyúl), Danube Region (e.g. Dunaföldvár, Paks, Dunaszekcső) and in Tolna Hills (e.g. Szekszárd, Iregszemcse, Miszla, Ozora). 

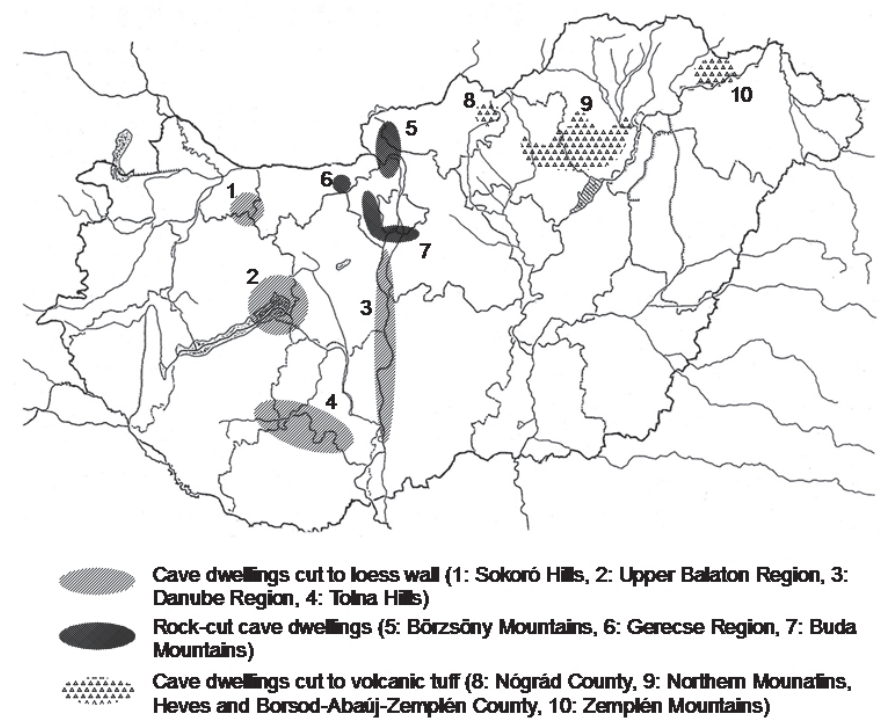

Figure 7: Cave dwellings in Hungary (self-made figure)

\subsection{The In-hill House}

The pit houses are considered as the archetype of in-hill houses. The floor of this ancient type of earth houses was sunk underneath the earth, the side walls were made of stone or wood and the roof was covered with earth.

In-hill houses can be formed typically on flat or on gently sloping areas. The architectural design, orientation and surfaces of the facade is more freely formed than in the case of the cave houses. It may happen that the building has only a front surface, but if required, additional openings may be implemented. Light and ventilation conditions may be more beneficial than the cave house conditions. The disadvantage is that mainly single-story floor plan is available and it has potential for large-area needs. The most ancient (more than 3000 year-old) in-hill houses called Skara Brae are located in Orkney Island (Scotland) (Fig. 8) [22].

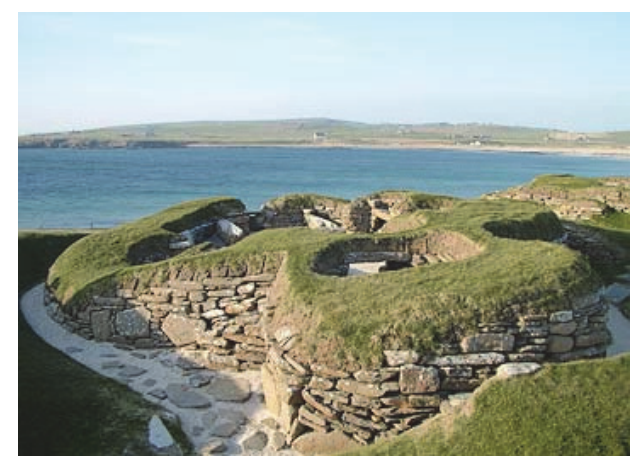

Figure 8: The ancients earth houses of Skara Brae (Orkney Island, Scotland) [22] 
This type of housing was also used and is still used today in North America by the Navajo Indians (Utah, USA). This traditional Navajo house called "Hogan" generally shaped like spherical dome with a transom light on the top (Fig. 9) [18] [20]. Shape of the ground plan is ordinary round or polygon, the frame structure is timber with earth covering. In California State (USA) a similar type of housing called "Mongollon" was used by the native Indians.

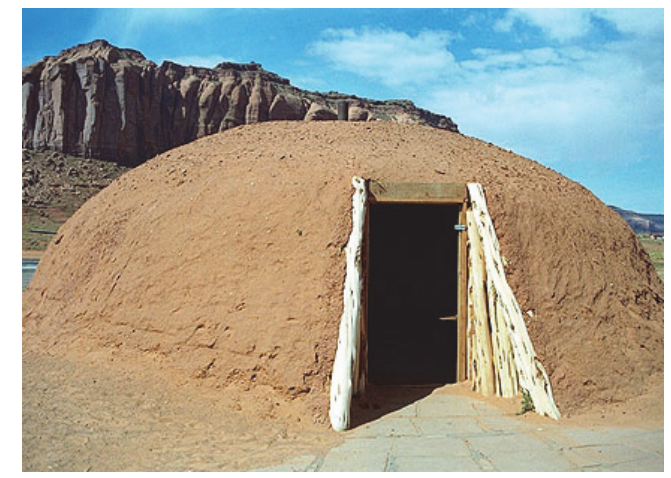

Figure 9: A Navajo "Hogan” [18]

While in-hill houses located in California and Utah were primarily covered with earth to protect interior against summer heat, in Europe and North America in-earth embedded houses and earth covering used as protection against hard winter frosts. In Alaska, Scandinavia, Iceland (Keldur, Sænautasel) and Russia (called "foxhole") were built in-earth embedded and soil-vegetation-covered houses.

\subsection{The Atrium House}

An atrium house can be built underground in flat landscapes. Side walls and roof covering are made of earth. The reason of the birth of atrium house - unlike the other two housing types - especially not winter cold, but protection against summer heat. The building has a central atrium space (patio) which is usually open at the top, and the residential rooms around it are grouped around the courtyard. Solid side wall surfaces completely lock the outside world out. The room lighting is possible only with roof skylight windows and openings to the inner courtyard.

We can meet with the ancient type of atrium house sin Mediterranean region, embedding into earth is more typical in North Africa and in the Middle East. The best known example of atrium houses we can find near the village of Matmata (Tunisia) (Fig. 10) [7]. Although primarily intended to protect against the summer heat, but the old days as an excellent hiding place they were able to mislead the enemy. During construction, at first approx. $5-15 \mathrm{~m}$ in width and the same depth, round-shaped hole is dug. Then starting from the side wall of the pit the rooms were cut into earth like tunnel building. Similarly buildings can be found in the village of Rocheménier (France). 


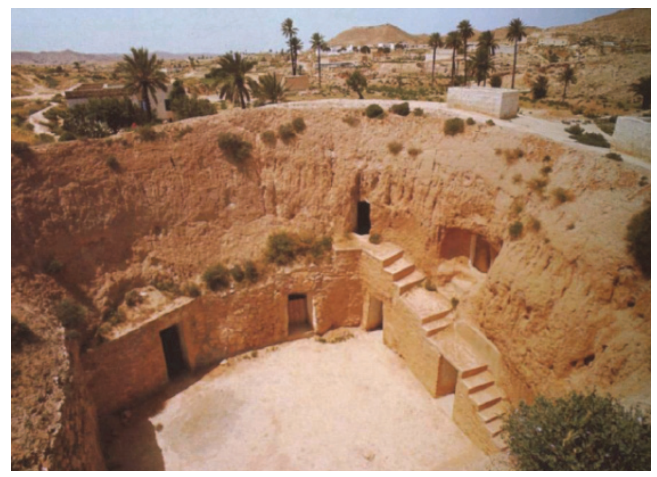

Figure 8: The courtyard of an atrium house is Matmata (Tunisia) [10]

\section{The Modernist Earth Architecture}

The roots of modern earth architecture can be found in the works of modern architect in the early 20th century. In 1926 Le Corbusier (1887-1965) formulated a principle in his work entitled Five Points of a New Architecture that says:

"Buildings should stand on pillars accordingly not to take place in nature, and allow vegetation below. Roofs should be flat and they need to be installed with vegetation."

These rules he applied for the design of Ville Savoye in 1929. The American architect, F. L. Wright (1867-1959) can be considered as a precursor of modern earth architecture. One of his most famous works is the Fallingwater house (Mill Run, Pennsylvania, USA), that was designed for E. Kaufmann (1885-1955) in the 1930s.

Designing this building the purpose of the architect was to bring up man and nature as close as possible. It came true with the mastery utilization of terrain and the conduction of stream through the house [4].

However the works of these outstanding figures of architecture were only harbingers of the campaign that we call modern earth architecture today. The main principles of this new architectural trend were born in the USA in the middle of the 20th century.

Malcolm Wells (1926-2009) is sometimes regarded as the „father of modern earthsheltered architecture". His first modern in-earth embedded residential building was built in Cherry Hill (New Jersey, USA) in 1964 (Fig. 11) [5]. 


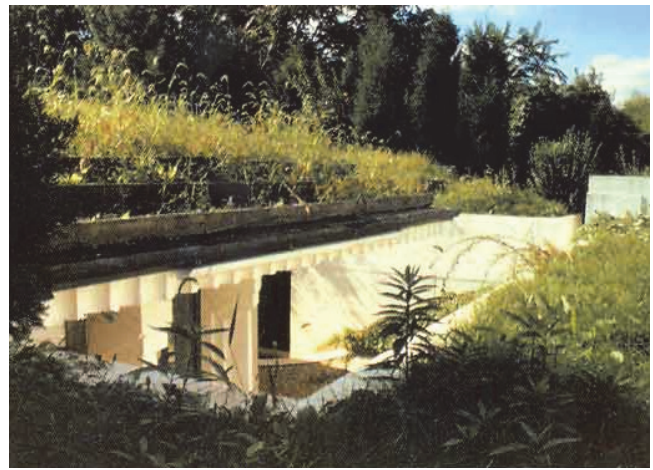

Figure 11: The earth house of Malcom Wells in Cherry Hill (New Jersey, USA) [5]

He found many followers after the oil crisis of 1973. This time people realised that the amount of fossil fuels are running out, and excessive energy consumption leads to a level of greenhouse gas emissions, that results global warming and climate change [5].

Since then, lots of designers proclaimed themselves as an earth architect and started their activities. In the United Kingdom the most important deputy of earth architecture was A. Quarmby, who designed the first modern British earth house in 1975 in Huddersfield, near Peak District National Park. Another important earth architects are the American M. Muenning (1935-), the Argentinian E. Ambasz (1943-), the Serbian V. Milković (1949-), and the Swiss P. Vetsch (1943-), who planned 47 earth houses since 1978. Vetsch's unique architectural design is a successful alloy of the style of A. Gaudí and Art Nouveau. Its famous Hungarian followers are Zs. Hegedüs, Zs. Kassai and I. Kovács (Fig. 12) [8] [17].

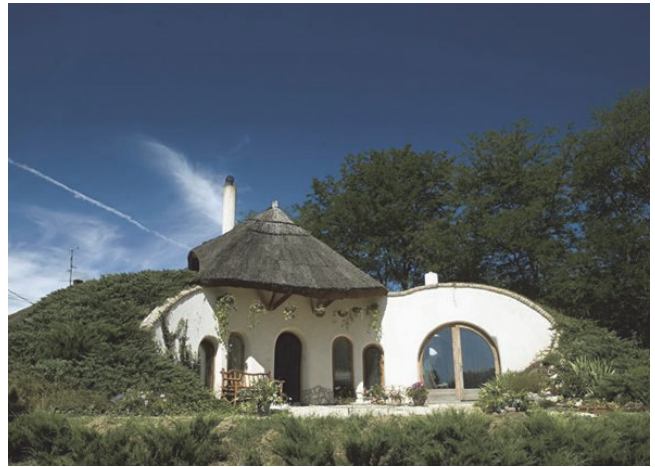

Figure 12: In-hill house planned by Zs. Hegedüs (Böny, Hungary, 2007) [8] [17]

\section{The Design Aspects of In-earth Embedded Houses}

One of the most important aspects is the configuration of terrain. On a steeply sloping terrain a cave dwelling is advisable. In-hill house and atrium house is more conceivable on a flat terrain [4]. 
The direction of sloping is also determining, because an in-earth embedded house has limited ways of facade openings. The southern side of the mountain is ideal for cave dwellings (on the northern hemisphere). From south the house more sunshine from south and it is easier to ensure enough natural lighting for the living spaces [15] [21].

Important influencing factor of designing is the specific climatic conditions dominating in the country. In Scandinavia the protection against cold and the maximization of winter sunshine utilization, in the Mediterranean region protection against summer sunshine and the shielding is primary.

The average rainfall and air humidity is also an important point of view. Planning the orientation of an earth house the main direction of wind is also a serious design aspect. On the northern hemisphere cold winter winds blow from north and northwest, so facades should not be opened in this direction [13].

It is essential to have regard to the soil conditions. Most essential soil properties to pay respect to are density, water permeability and thermal insulation quality. An ideal soil is relatively light (less gross weight to take into account), has low potential to erosion, leads easily the unnecessary rainwater away (no lasting moisture effects and risk of frost), has good thermal insulation quality and retains the vegetation well [3].

Unfortunately, these needs often lead to contradictions. Hard ground (e.g. clay) has advantage that it has less potential for erosion and good thermal insulation quality. At the same time water permeability of clay is low, this is why thermal motions and effects of frost are more dangerous.

The level of groundwater is also an important design aspect. The designer needs to find an area, where moisture can leek over easily otherwise serious groundwater pressure must be accounted during the structural design. Up-dammed water needs increased attention. It is recommended to ensure the excess moisture in the shortest possible way to escape away from the structure. It is available with plantation, landscape planning, a building out an appropriate drainage system.

\section{The Advantages of In-earth Embedded Houses}

In-earth embedded houses represent a special architectural trend, because they have not only aesthetic appearance, but they can be key elements of sustainable architecture because of their long lifespan and low energy consumption [4] [21].

Compared to conventional buildings, earth houses fit perfectly into their surroundings. A nicely designed earth house blends into the environment like it has always been there because of its low built-up area requirement. Large green areas can be developed on the building site. Proximity to nature provides a healthy home for residents. Unlike traditional buildings they can be more easier formed and built on sloping terrain [13].

Because of the thick earth-covering on the roof an in-earth embedded house is much less exposed to environmental effects like a traditional building. Because of the earthcovering an in-earth embedded house keep the heat in much longer, and it cools down slower. This thermal lag provides low temperature fluctuations inside. Air can filtrate through earth-covered walls and roofs uneasily this is why heated inside air cannot wind 
out so quickly. Consequently energy consumption of in-earth embedded houses is much lower than traditional buildings.

Earth-covering provides protection against extreme weather conditions like storms, hurricanes, tornadoes. Owing to its fire resistance, earth-covering features efficient fire protection. This is why earth embedded houses is preferred for fire safety reasons.

Not to forget either the excellent sound insulating properties of earth. A $60-300 \mathrm{~cm}$ thick earth-covering is able to absorb the noises of a busy highway. Inmates are completely isolated from the surroundings, so pleasant, relaxed living space guaranteed.

Illumination and ventilation problems can be solved with correct orientation and smart utilization of facades. With the help of careful planning an in-earth embedded house can be lighter and more airy like a traditional building.

\section{The Disadvantages of In-earth Embedded Houses}

It is a false belief that underground living areas are dark, narrow cold and damp. Due to this misconception most people are deals critical with the problems of in-earth housing that blocks them to spread widely [4].

They are designed with great care, skill and high level of knowledge in building construction, building materials and building physics. If the designer does not have these competences the interior climate of a poorly planned in-earth embedded building can be really unpleasant.

Inadequate ventilation can abuse the indoor air quality. It can cause humidity problems that can be solved only by installing expensive mechanical ventilation equipment. Wrong orientation and improper design of lantern-lights or windows lead to solar access troubles.

Maintenance costs of an in-earth embedded building are usually much lower than a traditional building an exception of one point of view.

Special attention should be paid for the attendance of roof gardens and to choose the quality of soil used for roof-covering (special mixture of soil is necessary) if we want to see a well-kept vegetation.

Another disadvantage might be that potential reparations (e.g. water leakage due to problems with the damp-course) can be performed only circuitously at the sacrifice of high costs. Unfortunately, the construction of an in-earth embedded residential building can be much more expensive than a conventional building because of the more careful planning, the better building material qualities and the more accurate construction standards.

It can frighten a lot of investor away especially if he is not aware to the relatively fast payback of construction costs during the operation.

Disadvantage is that most of the materials used in the construction of earth houses are artificial (concrete, plastic sheet waterproofing), so their production involves environmental pollution, and recycling is difficult. There are also ongoing experiments 
to these less environmentally friendly materials should be replaced (e.g. Eco-Flex waterproofing, earth and adobe bricks).

Although it can be expected architecturally unique that the ground plan of the most earth houses - mainly due to structural considerations - curved or irregularly shaped, but therefore these houses are more difficult to be furnished.

Among disadvantages should be mentioned the incompleteness in special literature and design specifications. Currently effective building regulations contain no specific passage for earth houses. Certain parts of paragraphs (e.g. floor level below terrain of rooms intended for permanent residence) can be interpreted in various ways.

Urban architecturally the spawn of earth houses may raise several doubts. The building instructions of resettlement plans (e.g. development in unbroken row, scattered development method) can hardly be observed by earth houses.

Also raise questions whether or not can be achieved, and if so, in what manner in densely built in and exposed to heavy traffic and air pollution metropolitan areas, where eco-building design is most needed.

\section{The Peculiarities of the Building Structures of In-Earth Embedded Houses}

Building in-earth embedded house needs much more earthwork, excavation and landscaping than a conventional building. Their supporting structure is most often dome or shell structure because this structure is the most appropriate for resisting stress (earth pressure for the walls and roof), keeping the unnecessary moisture away and elimination of illumination problems (e.g. skylights placed on the top of the dome structure).

It is important to emphasize to pay careful attention to the planning and implementing of insulation (thermal insulation and damp-proofing). Ideal insulation materials (because of the unusually and irregular surfaces) are the coatings].

\subsection{The Supporting Structures of In-earth Embedded Houses}

The choice of structure materials is mainly affected by the building design, the in-site conditions and the extent of bedding into earth.

Thicker layer of earth necessitates stronger loam-bearing structure. Reinforced concrete is the most common material for creating supporting structures of in-earth embedded houses. Although it is not the most environmentally friendly building material its strength, durability and fire resistance is a great benefit compared to other materials.

Prefabricated and monolithic reinforced concrete is also applicable. A structure made of reinforced concrete can be combined with other materials (e.g. reinforced concrete walls and wood roof structure).

Steel structure is also conceivable as supporting structure of an earth house. It has relatively small structural self-weight and high tensile and compressive strength. Its main disadvantage is poor fire resistance and susceptibility to corrosion. 
Rarely masonry structure (stone, brick, adobe, earth brick) can be used, but at higher load and stresses it should be strengthened with steel insets or additional reinforced concrete structures. As the reinforced concrete the most common form of masonry structures is also spherical dome, however it is more environmentally friendly and cheaper. Small bricks and (with cement or lime) stabilized earth brick masonries (e.g. BIOECO bricks) are the most popular (Fig. 13) [17].

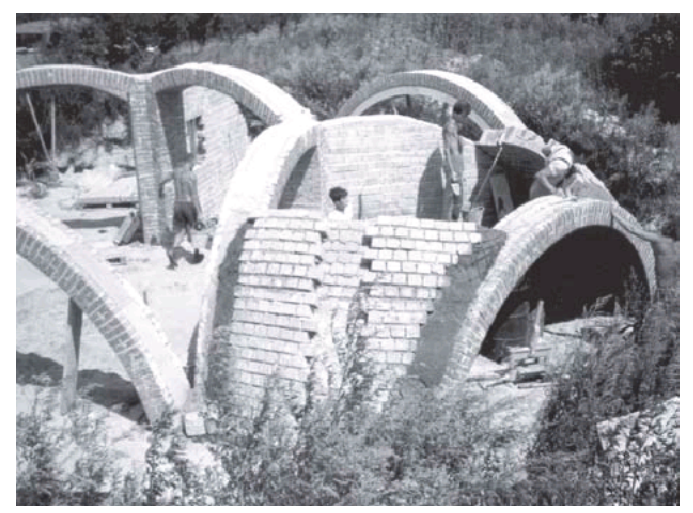

Figure 13: Masonry structure of the earth house in Tököl (Hungary) [17]

Wood is also an ordinary structural building material. Construction of a timber frame structure can be attractive for environmentally conscious architecture because of its natural origins (Fig. 14). Supporting power of it is not as high as a steel or ferroconcrete construction so it has applicability limitations. In addition it is less resistant to moisture, heat (e.g. fire) and pests (insects, rodents). Wood structures can be guarded against them with wood preservatives additives and coatings.

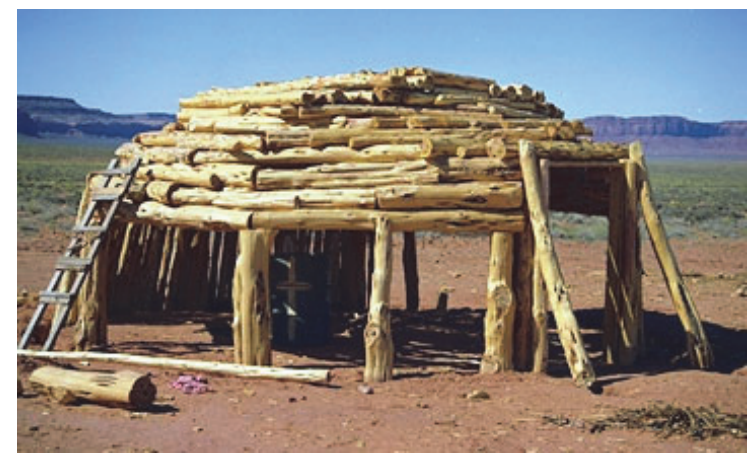

Figure 14: Wood structure of the Navajo Hogan (Utah, USA) [20]

Steel and reinforced concrete structure can be used together as a plastically formed shell structure. At first with spacers reinforced double steel frame structure is built. Then a fine woven steel mesh is attached. The external and internal side gets shotconcrete layer (Fig. 15). 
The space between the two shot-concrete layers can be filled by thermal insulation. Less thermal bridge, quick construction, possibility of large spans and unnecessary of formworks are its main benefits (Fig. 16).

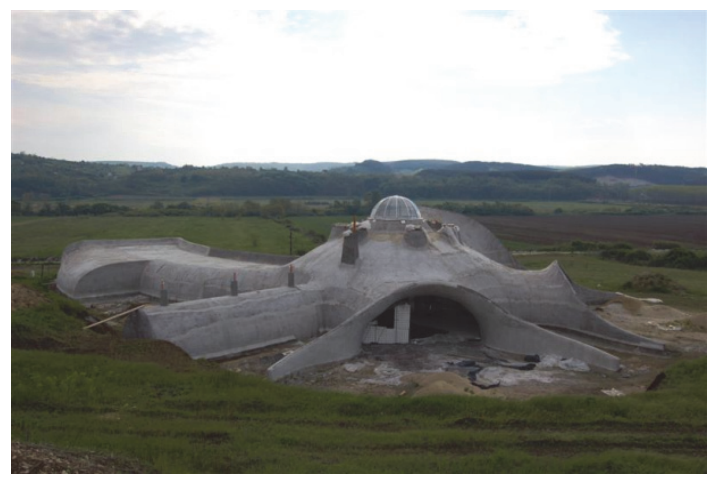

Figure 15: Supporting structure of an in-hill house (Egerszalók, Hungary) [21]

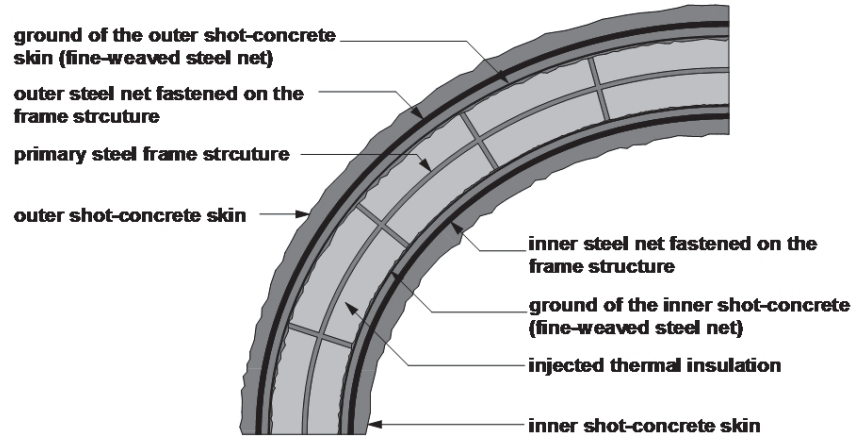

Figure 16: The stratification of the plastically formed shell structure (self-made figure)

\subsection{The Problems with Damp-Proofing of In-earth Embedded Houses}

As any structure contacting with soil, the interior of an in-earth embedded house also needs protection against harmful effects of moisture. Similarly to green-roofed constructions the protection of damp-proofing membrane against roots is substantial.

At lower damp-proofing requirements, when only particular impermeability required, the supporting structure itself can be watertight (e.g. watertight concrete). Moreover we can use watertight plaster on the inner or outer side of the wall structures [3].

In all residential buildings total impermeability should be provided. Most prevalent damp-proofing technologies are membrane and coating insulation. One of the most important damp-proof membrane insulations is the modified bituminous membrane During their preparation synthetic rubber additives is mixed with bitumen and then this mixture is carried up to a polyethylene mesh. They have long life expectancy and they are stickable to outer walls. Unfortunately unusual, irregular surfaces and shell structures are uneasy to insulate with it [15][16]. 
Useable plastic damp-proofing materials are polyethylene (PE), chlorinated polyethylene and polyvinyl chloride (PVC) membranes. They are cheap and durable but UV radiation can damage them, so almost immediately after their placement protection from degradation due to solar radiation is necessary. The most commonly used elastic materials are polyisobuthylene (PIB), polychloroprene and ethyl-propylene-diene (EPDM) plastic damp-proofing membranes. EPDM membranes have integrated protection against roots, but they are heavily stickable and some pests (e.g. fire ant) can bite it through. Plastic waterproof materials are not so environmentally friendly because they are petroleum products.

The other important group of damp-proof materials are coating insulations. This technology means that the liquid waterproofing material is applied (spraying, brushing) on the surface to be insulated. After drying it forms damp-proofing membrane.

Coatings are easily practicable moreover they have no splices. Nevertheless they can be easily damaged and their implementation is proposed under relatively warm and dry weather (so attention to weather conditions should be paid). Generally they are used in places where implementation of membrane insulations is impossible. Most often used coating insulations are bituminous emulsion and liquid polyurethane.

Sometimes bentonite damp-proofing occur insulating in-earth embedded houses. Bentonite is clay mineral from which insulating plates are prepared which are fixed on the outer side of the wall. They are rarely used because of their high self-weight and difficult installation. There is also bentonite coating insulation.

\subsection{The Thermal Insulation of In-earth Embedded Houses}

Thermal insulation quality of earth is a special problem. Depending on moisture content, density and compound thermal conductivity $(\lambda)$ of earth is ranged between $0,15-2,00 \mathrm{~W} / \mathrm{mK}$, which is much lower than the thermal conductivity of the most common building insulation materials. But - unlike thermal insulation materials - the thickness of earth-covering is much larger (it can be more than 1,0 m). Because of its large mass (and thermal lag) it is able to reduce the effects of outer temperature changes, so it can prove adequate thermal protection for residential building. Due to this beneficial effect thermal insulation of in-earth embedded houses much less energy needs to be paid a sin a conventional building [1][4].

The earth-sheltering acts positively upon the interior climate of the building. It gives protection from the solar radiation. By reducing thermal fluctuation on the outer surface of the roof and by increasing their thermal capacity, earth-sheltering contributes to the cooling of the spaces below the roof in the summer and to the increase of their heat during the winter. Due to the decrease of the thermal losses earth-covering saves the energy consumption [10].

On basis of researches the surface temperature of earth-covering varies according to the different kind of vegetation. Lower temperature measured in the spaces, which are covered by thick, dark green vegetation and higher in spaces, which are covered by sparse red vegetation or only soil. During the summer period the external surfaces with the earth-covering are heated less than traditional roofs. Besides, in the winter period the planted roofs reduce the heat loss. Greek scientists showed that the estimated 
heating and cooling loads are lower in the building with earth-sheltering [10]. The greatest energy savings during the whole year period were calculated in the case of noninsulated buildings $37 \%$, which increased to $48 \%$ when advanced cooling was applied. The total energy saving consumption in case of moderate insulated buildings varied from $4 \%$ till $7 \%$ (with or without advanced cooling). The impact of earth-covering on the energy savings of well-insulated buildings was almost $2 \%$.

Several buildings have been built on the basis of assumptions that earth-covering is itself sufficient and no added thermal insulation layer was built in. However, this is only allowed between specific climatic conditions. In cold and temperate climates appropriate indoor air temperature cannot be ensured in all seasons without extra thermal insulation.

Basically, two types of thermal insulation technology used. One option is to place the insulation outside of the waterproofing membrane. In this case, the insulating layer is considered as soil-contacting structure. Thus, only a material is allowed to use for this purpose, which does not lose its insulating ability under permanent moisture effects. For this purpose there are some plastic foam insulation materials (such as extruded polystyrene foam) [16].

Another way of insulation is the on-site foamed (sprayed or brushed) thermal insulation products (such are polyurethane foam) with which practically any surface can easily be insulated. In order to keep water away the protective layer must be overlaid on it.

\section{Conclusions}

Residential buildings embedded into earth always served as human shelters. Natural caves, in-hillside cut cave dwellings and in-ground pitted houses were the archetypes of earth houses that modern earth architecture calls cave, in-hill and atrium houses today.

Basic principles of modern earth architecture were expressed by the first modernist architects in the 1930s (such as Le Corbusier and Wright) but the really idea of in-earth embedded houses came to forward only after the first oil crisis in the 1970s. In this time the environmental and energy conscious architecture became a matter of common knowledge which greatly contributed to revalue several advantages of in-earth embedded houses: e.g. the excellent fit to the environment, low energy consumption and protection of indoor living space against external environmental effects (e.g. noises, wind and the fluctuation of temperature). In order to utilize the benefits of in-earth building more thoroughly examined design is required comparing to the design of any conventional residential buildings.

As an example particular attention should be paid to the topographical, climatic and soil characteristics. In addition to this, the architect must have excellent knowledge of building construction and building physics to have capacities in solving the structural, lightning, solar, ventilation and humidity questions derived from the peculiar relation with the earth. 
The correct orientation, the floor plan design, the landscaping and the selection of the materials are the essential questions, because an incorrectly designed building may be easily narrow, damp, dark and cold, therefore unsuitable for human habitation.

For supporting the structure of in-earth embedded houses, dome or shell structures are the most suitable. Structural material is commonly reinforced concrete, but other materials (steel, wood, stone, adobe, and clay bricks) are also adequate. The most important issues are damp-proofing and thermal insulation.

Earth-covering has positive effect on indoor climate. It protects the outdoor surface from solar radiation and reduces the indoor thermal fluctuation. Earth-covering decreases thermal losses in winter and warming up in summer. This is why it saves energy consumption. Without extra thermal insulation heating and cooling loads are 37$48 \%$ lower, than in case of a non-insulated building and $2-7 \%$ lower than in case of insulated buildings. Sometimes in cold and temperate climate extra thermal insulation is needed. It can be solved with extruded polystyrene foam or monolithic foamed, sprayed or brushed insulation materials, such as polyurethane foam.

Because of their disadvantages (relatively high building costs, lack of standards and regulations, strict design aspects) in-earth embedded houses are built relatively rarely nowadays. But as they spread widely the negative stereotypes (damp, dark and cold) wear away. Slowly they are becoming increasingly popular and expectedly succeeding architects have to design more and more in-earth embedded houses in the future.

\section{References}

[1] Al-Temeemi AA, Harris DJ: A guideline for assessing the suitability of earthsheltered mass-housing in hot-arid climates. Energy and Buildings Vol. 36, No. 3, pp. 251-260, 2004.

[2] Batár A: The Invisible Cave Dwellings (in Hungarian). Ab Ovo Publisher, 2005.

[3] Bica S, Rosiu L, Radoslav R: What Characteristics Define Ecological Building Materials. $7^{\text {th }}$ IASME/WSEAS International Conference on Heat Transfer, Thermal Engineering and Environment, Moscow (Russia), 20.08.2009-22.08.2009, pp. 159-164, 2009.

[4] Bozsaky D: In-earth Embedded Residential Buildings (in Hungarian). Magyar Építőipar, Vol. 60, No. 3, pp. 109-115, 2010.

[5] Braham W: Malcom Wells, 1926-2009, Williambraham.net - Ecology, Technology and Design, 06-12-2009 http://williambraham.net/?p=192 (downloaded: 19.10.2009)

[6] Dám L: In-earth Embedded Residential Buildings in the Native Architecture of the Alföld (in Hungarian). A nyíregyházi Jósa András Múzeum évkönyve, 33-35 (1990-1992), Jósa András Múzeum, Nyíregyháza (H), pp. 133-151, 1993.

[7] Fajszi B: Discovering Tunisia Independently (in Hungarian). Útikalauz.hu/Tunézia/Fajszi Bence: Önállóan felfedezni Tunéziát, 2004. szeptember. http://www.utikalauz.hu/index.php?p=folap\&id=868 (downloaded: 02.04 .2010$)$ 
[8] Hegedűs Zs: In-hill Houses in Bőny (in Hungarian). Magyar Építőművészet 4/2007.

http://magyarepitomuveszet.mm-art.hu/hu/paholy_design.php?lapszam=2007$4 \& \mathrm{id}=859$

(downloaded: 19.10.2009)

[9] Mednyánszky M: Cave houses in Hungary (in Hungarian). Terc Kiadó, Budapest, 2009.

[10] Niachou A, Papakonstantinou K, Santamouris M, Tsangrassoulis A, Mihalakakou G: Analysis of the earth-covering thermal properties and investigation of its energy performance. Energy and Buildings Vol. 33, No. 7, pp. 719-729, 2001.

[11] Ortutay Gy (ed.): Cyclopaedia of Hungarian Ethnography Vol. 2 (in Hungarian). Akadémiai Kiadó, Budapest, 1979.

[12] Ortutay Gy (ed.): Cyclopaedia of Hungarian Ethnography (in Hungarian). Akadémiai Kiadó, Vol. 4, Budapest, 1981.

[13] Roy R: Earth-Sheltered Houses: How to Build an Affordable Underground Home. New Society Publishers, Gabriola Island (Canada), 2006.

[14] Yong X: Inside the yellow earth. Beifan.com/China Postcards/Xu Yong: Inside of the Yellow earth, July 1996.

http://www.beifan.com/044postcards/page01.html (downloaded: 04.06.2011)

[15] Anon: An introduction to earth sheltering. The British Earth Sheltering Association/An introduction to earth sheltering http://www.besa-uk.org/intro.html (downloaded: 04.06.2011)

[16] Anon: Building Earth Sheltered Homes. Earth Sheltered Homes - Residential, Commercial \& Multi-Family Construction http://www.earthshelteredhome.com/index.htm (downloaded: 02.04.2010)

[17] Anon: Zsolt Hegedüs (in Hungarian).

Élőépítészet.hu/Épületek/Építészek/Egyesülésen kívüli építészek

http://eloepiteszet.hu/hu/epuletek/epiteszek/egyesulesen-kivuli-epiteszek/hegeduszsolt

(downloaded: 19.10.2009)

[18] Anon: Hogan - The Navajo Dwelling, Max Bertola's Southern Utah/Feature stories about southern Utah/Hogan - The Navajo Dwelling http://www.so-utah.com/feature/hogan/homepage.html (downloaded: 04.06.2011)

[19] Anon: Matera, Wikipedia - the free encyclopedia /Matera http://en.wikipedia.org/wiki/Matera (downloaded: 19.10.2009)

[20] Anon: Native American Shelters - Southwest, Minnesota State University/Emuseum/Prehistory/Settlements/Southwest http://www.mnsu.edu/emuseum/prehistory/settlements/regions/southwest.html (downloaded: 02.04.2010)

[21] Anon: Free-formed Houses Under The Earth (in. Hungarian). Koos.hu/zöld/2007 http://koos.hu/2007/11/28/szabadformaju-szendvicshej/ (downloaded: 25.08.2014)

[22] Anon: Orkney's Underground Earth-houses, Orkneyjar.com/History/Earth Houses http://www.orkneyjar.com/history/earth-houses/ (downloaded: 19.10.2009) 